\title{
Evaluation And Use Of Special Collection Perspective Of KNLS
}

\author{
Dr. Henry D. S. Kinya \\ Rongo University \\ Rongo -Kenya.
}

\begin{abstract}
Users in public libraries' needs are changing, technology is changing, the economic environment is changing, distribution of information channels are changing and so, Public libraries should change their roles and approaches to achieve its goal by availing of special collection and special services to users. In assisting information users to access and use not only online special information services but also access other websites special collection services the role of public libraries within the information age context is changing from that of information provider to that of service provider and so is the roles of librarians; changing its old-age manual operations of print to print service to that of library networking to facilitate information sharing services and activities fundamentally requires the new dimension of trained and available enabling environment of ICT in public library system in Kenya. Users' opinion, views and feelings account most in the fulfillment of the core objectives the Public library is established for. This paper, discusses the public library special collection in the format of; rare books, manuscripts, photographs, archives, artifact, historical photos, unique materials and pamphlets. Therefore researcher has surveyed them in all $32(100 \%)$ public libraries in Kenya. This research paper is further, intended to help public libraries librarians, managers and management to decide how to integrate ICT resources special collection in such a way that most users can understand them well enough to make productive choices to foster research. It compiles usability test data evaluating special collection and services offered in library public libraries in Kenya. This research paper describes the progress and application of a fundamental comparison typical which allows librarians to quantitatively measure library special collection services apparent quality, satisfaction and constancy with a library as well as the degree to which exact elements of a library's program, collections and setting donate to those perceptions.......Library professional protocol and standards are in safe hands of both users and staff who are skillfully trained in technical, analytical and information management and repackaging skills; to further provide library information services like subject specialists and subject analyst equipped with special skills to deal with children information needs and users with special needs. In this paper special collection and special services offered to special users in Kenya National Library Services (KNLS) via public libraries in Kenya has been discussed.
\end{abstract}

Keywords: public libraries, public libraries special collection, special collection development, users of special collection, rare collection and unique materials.

\section{PREAMBLE}

Productive contribution and the development of democracy depend on acceptable education as well as on free and unlimited access to thought, culture and information. As per UNESCO public library manifesto (UNESCO, 1994), the public library, the local gateway to information make available a basic condition for lifelong knowledge, sovereign decision-making and cultural development of the individual and social groups. Public libraries are instruments of equal opportunity and must provide a safety- network with technological advancement by becoming the electronic doorway to information in the digital age. They should enable all citizens to have access to the information that will enable them to manage their lives at the local level, to acquire essential information about the democratic process and to participate positively in an 
increasingly global society. The public library's role is becoming one of mediator, of being the publics' electronic doorway to digital information and of helping citizens cross the 'digital divide' to a better future. Whereas, the librarian's role is increasingly becoming as of 'information navigator' ensuring that they are part of information policy and user gets accurate and reliable information (IFLA, 1994; Sager, 1984).

By providing a wide range of materials and activities, public libraries provide an opportunity for children to experience the enjoyment of reading and the excitement of discovering knowledge and works of the imagination. Children and their parents should be taught how to make the best use of a library and how to develop skills in the use of printed and electronic media.

Special collection is defined as the group of items, such as rare books or documents, that are either irreplaceable or unusually rare and valuable; for this reasons special collection are stored separately or off site from the regular library collection, in a secure location with environmental controls to preserve these information items for posterity. Public libraries have a special responsibility to support the process of learning to read, and to promote books and other media for children. The library must provide special events for children, such as storytelling and activities related to the library's services and resources. Children should be encouraged to use the library from an early age as this will make them more likely to remain users in future years. In multilingual countries books and audiovisual materials for children should be available in their mother

Young people between childhood and adulthood develop as individual members of society in their own culture. Public libraries must understand their needs and provide services to meet them. Materials, including access to electronic information resources, which reflect their interests and culture, should be provided. In some cases this will mean acquiring materials that represent youth culture, in a variety of media that are not traditionally part of a library's resources, for example, popular novels, book and television series, music, video tapes, teenage magazines, posters, computer games, graphic novels.

It is important to enlist the help of young people in selecting this material to ensure that it reflects their interests. In larger libraries this material, with appropriate furniture, can form a special section of the library. This will help them to feel that the library is for them and help to overcome a feeling of alienation from the library, which is not unusual among this age group. Relevant programs and talks to young adults should also be provided Tongue (IFLA, 1994).

Public libraries represent an indispensable link in the scientific system chain, a crucial role link in the development and maintenance of wide range and intensity of knowledge modernization and ideas in society and at individual level.

\section{PROPOSED RESEARCH}

Many information scientists have used different terms for public library system study. The recognition of public library first took place in western-Saxon countries. The term public library first appeared in Latin (bibliotheca publica) as a technical term in $17^{\text {th }}$ century to distinguish the general university libraries of Oxford and Cambridge by then from those of endowed libraries. The historical combination of the growth of printing, public education, democratic institutions and urbanization during 19 $19^{\text {th }}$ century led to the establishment and development of public libraries in USA and UK. UNESCO stated that the public library is the principal means whereby the records of man's thoughts and ideas and the expression of his imagination are made freely available to all' 
In 1977 D J Fosket describes the public library system as 'the central feature in the concept of whole entities, whose parts are linked by specific pattern of relation; the system as a whole is greater than the mere sum of its parts by virtue of this pattern.

Kumar (2004) defined public library system as 'a A combination of people, activities, events and object resources working together to convert inputs to outputs'

Public libraries are libraries serving the community or region with multipurpose informationeducation -culture, agency in respect of information dissemination services, free of charge or at nominal fee (Thompson, 1974).

Special collection: Refers to the group of items, such as rare books or documents, that are either irreplaceable or unusually rare and valuable; for this reasons special collection are stored separately or off site from the regular library collection, in a secure location with environmental controls to preserve these information items for posterity.

Public library system: Refers to the communication of ideas and information for any type of users for their inseparable utilization in the promotion of democratic development of education to raise their economy as a result of sincere participation. Mostly it takes a pyramidal structure in nature with, state central libraries, district central libraries and village libraries (Iyer, 1999). ]

Kenya national library services (KNLS): The Kenya National Library Service (KNLS) Board is a national corporation established by an Act of Parliament, Cap 225 of the Laws of Kenya in 1965 the Board commenced its mandated functions in 1967.

Board is empowered to develop public library services in Kenya to fill the vacuum that existed before and soon after independence regarding the provision of public library services hence bridge the level of literacy. The headquarters library in Nairobi opened its doors to the public in 1969. Currently, the Board is responsible for managing 8 libraries in 8 provinces and over 32 libraries spread throughout the country at district level.

\section{Objectives of the study}

The fundamental principle of creating a national public library network is to provide information and library services to users. The basic purpose of the study was to evaluate availability and use of special collection in KNLS. The specific objectives of the study are:

1) To evaluate the availability and use of special collection in public library system in Kenya;

2) To assess the applicability and frequency of special programs in public library system in Kenya;

3) To suggest and recommend best practices for usage of special collection and special programs in public library system in Kenya.

\section{Hypotheses}

The researcher, initiated the process of investigation, and so it resorted to the following hypothesis for the study:

1) Cultural and social situation of the country has its impact on public library system;

2) Public libraries in Kenya are economically disadvantaged;

3) Manpower development in Public libraries in Kenya is in the developing stage; 


\section{Scope and limitations}

Scope of the study was limited to the evaluation and use of special collection in public library y system in Kenya e.g. KNLS.

\section{Research methodology}

Present study the researcher had employed a survey method and had applied questionnaire, interview and observation as data collection techniques. A survey is one of the most effective and sensitive instrument of research which produces much needed knowledge.

\section{Special collection and services}

Attempts were made to collect data and analyze on library programs outside the library from $32(100 \%)$ libraries, which is presented in table 1.1

Table No.1,1: Library special collection and programs

\begin{tabular}{|c|c|c|c|c|c|c|c|}
\hline $\begin{array}{l}\text { Library } \\
\text { name }\end{array}$ & $\begin{array}{l}\text { Special } \\
\text { needs group } \\
\text { materials }\end{array}$ & $\begin{array}{l}\text { Local } \\
\text { unique } \\
\text { materials }\end{array}$ & $\begin{array}{l}\text { Rare } \\
\text { collection }\end{array}$ & $\begin{array}{l}\text { Cultural, } \\
\text { Drama\& } \\
\text { exihibitions }\end{array}$ & $\begin{array}{l}\text { Special } \\
\text { equipment }\end{array}$ & $\begin{array}{l}\text { Children's' } \\
\text { programs }\end{array}$ & Total \\
\hline Nairobi & 8 & 4 & 4 & 4 & 2 & 5 & 27 \\
\hline Buruburu & 1 & 3 & 2 & 0 & 0 & 0 & 6 \\
\hline Mombasa & 2 & 1 & 0 & 1 & 1 & 4 & 9 \\
\hline Kwale & 1 & 2 & 0 & 2 & 1 & 2 & 8 \\
\hline Kilifi & 4 & 2 & 6 & 2 & 4 & 5 & 23 \\
\hline Voi & 4 & 2 & 2 & 2 & 0 & 2 & 12 \\
\hline Kisumu & 2 & 1 & 1 & 1 & 1 & 1 & 7 \\
\hline Kisii & 5 & 2 & 0 & 0 & 0 & 1 & 8 \\
\hline Ukwala & 2 & 0 & 0 & 1 & 1 & 0 & 4 \\
\hline Nyilima & 5 & 2 & 2 & 0 & 0 & 1 & 10 \\
\hline Awendo & 10 & 0 & 0 & 0 & 0 & 1 & 11 \\
\hline Embu & 5 & 1 & 0 & 2 & 1 & 1 & 10 \\
\hline Meru & 2 & 0 & 0 & 0 & 1 & 1 & 4 \\
\hline Mwingi & 1 & 1 & 0 & 0 & 0 & 2 & 4 \\
\hline Kithasyu & 5 & 1 & 2 & 1 & 3 & 2 & 14 \\
\hline Nakuru & 4 & 1 & 1 & 0 & 1 & 2 & 9 \\
\hline Eldoret & 20 & 1 & 3 & 1 & 5 & 2 & 32 \\
\hline Kabarnet & 2 & 1 & 0 & 0 & 1 & 0 & 4 \\
\hline Kericho & 1 & 1 & 4 & 0 & 3 & 2 & 11 \\
\hline Silibwet & 1 & 1 & 0 & 0 & 0 & 0 & 2 \\
\hline Kapsabet & 0 & 1 & 0 & 1 & 0 & 5 & 7 \\
\hline Laikipia & 1 & 1 & 1 & 0 & 0 & 1 & 4 \\
\hline Rumuruti & 2 & 1 & 0 & 0 & 1 & 1 & 5 \\
\hline Nyeri & 4 & 2 & 1 & 0 & 0 & 1 & 8 \\
\hline Thika & 2 & 1 & 0 & 0 & 1 & 1 & 5 \\
\hline Naivasha & 0 & 1 & 2 & 0 & 0 & 2 & 5 \\
\hline Karatina & 0 & 1 & 0 & 0 & 0 & 1 & 2 \\
\hline Olkalou & 1 & 1 & 1 & 1 & 1 & 1 & 6 \\
\hline Kakamega & 0 & 0 & 1 & 0 & 1 & 2 & 4 \\
\hline Garissa & 1 & 1 & 2 & 1 & 1 & 1 & 7 \\
\hline Wajir & 1 & 2 & 1 & 1 & 1 & 2 & 8 \\
\hline Mandera & 2 & 1 & 2 & 1 & 1 & 5 & 12 \\
\hline total & 99 & 40 & 38 & 22 & 32 & 57 & 288 \\
\hline
\end{tabular}


It can be observed from the table No 1.1 that in Kenya all libraries has and provides a range services from special needs group materials, local unique materials, rare collection, special equipment, cultural, dramas and exhibitions, and children's programs as part of KNLS policy to take the library to the users, publicize the library and creating awareness to the users, however, from the data it can be observed that these programs all the same they are duplicated all over the $32(100 \%)$ libraries, making them lose the objectivity of these programs, it was observed that due to the limited resources and financial constrains KNLS was not able to organize recent programs to replace the old ones. This confirms the hypotheses 'public libraries in Kenya are economically disadvantaged' (Hypothesis No 2)

\section{Provision of special collection services}

General acquisition and discard rates may not be relevant to some parts of the collection or to particular special collections or where special circumstances prevail. In these cases the collection policy must reflect the special needs. Particular examples of these exceptions are:

- indigenous resources - the public library has a role in maintaining and promoting collections of resources related to the culture of indigenous people and ensuring access to them

- local history resources - material relating to the history of the locality should be actively collected, preserved and made available

- libraries in communities with a high proportion of particular groups, e.g., children, retired people, young adults, indigenous peoples, ethnic minorities or unemployed people should reflect the needs of these groups in their collections and services.

- reference collections - older reference material may need to be retained to provide historical data for research.

\section{FINDINGS}

\section{Special collection and special user groups in KNLS}

Potential users who, for whatever reason, are unable to use the regular services of the library have a right to equal access to library services. The library should, therefore, establish ways of making library material and services accessible to these users. These will include:

- special transport, e.g., mobile libraries, book-boats and other forms of transport to serve those living in isolated areas

- $\quad$ services taken to the home of those people who are housebound

- services taken to factories and industrial premises for employees

- $\quad$ services for those confined in institutions, e.g., prisons and hospitals

- special equipment and reading materials for those with physical and sensory disabilities, e.g., hearing impaired and visually impaired people

- special materials for people with learning difficulties, e.g., easy-to-read materials and cassettes

- $\quad$ services for immigrants and new citizens to help them to find their way within a different society and to provide access to media of their native culture

- electronic communication, e.g., Internet catalogues.

Services for people with special needs can be enhanced by the use of new technology, for example, speech synthesizers for the visually impaired, online access catalogues for those in isolated areas or unable to leave their home, connections to remote sites for distance learning. Mainstream service provision, for example, public access catalogues (OPACs) can often be adapted to meet the needs of those with physical and sensory disabilities.

Those who can benefit the most from technological developments are often the least able to afford the investment needed. Innovative schemes should, therefore, be developed by the 
public library to exploit the new technology in order to make services available to as many people as possible.

Services for ethnic groups in the community and for indigenous peoples should be developed in consultation with the group concerned. They are likely to include:

- the employment of staff from the group in the library

- collections including the native literature of the group and reflecting the oral tradition and non-written knowledge of the people.

- the application of special conditions, developed in conjunction with local people, to culturally sensitive material (Moore ,1989).

\section{Other programs un- attended}

Try to stretch their resources to fill gaps left by insufficient services and resources elsewhere. Even when special social support services -e.g., children programs, exhibitions, talk lecturers, cultures and dramas, special groups, illiterate, and other services not offered by KNLS to the disadvantaged community for they do not experience and feel the impact by these programs deemed to be offered by KNLS. Further, from the research it can be observed that these programs all the same they are duplicated all over the 32(100\%) libraries, making them lose the objectivity of these programs, it was found that due to the limited resources and financial constrains KNLS was not able to organize recent programs to replace the old ones.

KNLS in its changing role is assisting the users to access and use not only online special collection information services but also access other special collection websites services like archives, historical and indigenous materials and print services. Users with special needs to speech synthesizes on line special collection catalogue services to those in confined institutions e.g hospitals, prisons and mobile libraries. This is the role of public libraries within the information age context which is ever changing from that of information provider to that of service provider. (Table 1.1); Changing its old-age manual operations of print to print service to that of library networking to facilitate information sharing services and activities to all categories of users.

\section{RECOMMENDATIONS}

KNLS through its library networks has the considerable potential to improve library services in several ways; bring down the cost of information products and services in the network environment in a shared mode, offer need-based services to the end users eliminating the limitation of size, distance, and language barriers. Linking all the headquarters of the five east African countries (Kenya, Tanzania, Uganda, Rwanda and Burundi) their national Public library systems, in the first phase, and then followed by other major cities. This will be done under the umbrella of the newly signed treaty, East Africa Community. The treaty encompasses all areas of common interest in sharing resources and exchange of human resources, and tax exemptions. Once this link is done, then the entire East Africa region will have access to the entire library holding of each country and will share that experience for better services provision.

Specifically, it is recommended that the KNLS public library network, including the Community Libraries. Liaise with government agencies, especially those that have high impacts on public libraries, to develop memoranda of understanding that acknowledge, support and fund the role of public libraries in providing access to, and delivery of, information resources and services. Users' needs specifically on special collection services through the changing technology which is changing, the economic environment is changing, distribution of information channels are changing and so, KNLS should change its roles and approaches to achieve its goal. 
Further on the same KNLS to develop links with other libraries outside KNLS, the physical entities to resources are diminishing day by day with evolution of library network which offers network accessible special collection and services resources in all connected databases of library holdings in the present age of information technology. This should be the strategic plan for KNLS for the next ten years, to ensure it has developed information protocol agreement with academic and special libraries in the country to facilitate library networking and be main player in the information dissemination with the country, for this is the new breed of library profession for development of library services. Its known fact that most of the library collection especially universities are underutilized scientific and technical collection which once they are made available through library networking can be useful to KNLS on its diverse users.

Conduct follow up research in three years time to assess the ongoing impact of ICT on special collection and services to its users through KNLS public libraries network and the ability of the network to respond to the demands of users created by information services and right to information policies. The assessment should be complemented by regular customer surveys to establish what KNLS and information services- special services the public wants, at what level, and how they judge all categories of services they receive. Survey work being a specialist skill and, where resources are available, a more objective result will be gained if the survey is carried out by an external organization. The available KNLS network technical skills should be transformed to be having better communication skills, managerial skills, training skills and facilitation skills. These skills are acute and specific in enhancing better services to the users of KNLS in this era of technology. Staff will further acquire information analysis skills, repackaging, consolidation, technical reporting and downloading both structured and unstructured information available through internet for users.

Lastly, another important observation made by the researcher was that of the digitalization in reference section. These sections were once the most used part of the public library, but it is rapidly becoming a thing of the past. The internet information is taking over from printed reference works and collections, leaving chiefly periodicals and maps in use. The information services, it was observed provided reference libraries are merging with other information services. The future of reference sections in public libraries is and will be of great concern as well as open question in the entire of KNLS fraternity, for their existence will endure, but their format will have to be clearly being definite in the policy level along site incorporating ICT. KNLS should opt for the best firmly established model for adapting reference operations to the digital age; KNLS to acquire user rights to expensive material that individual people cannot afford to obtain. These are reference material and international press database can be exclusively be used in the KNLS public libraries in providing special collection, reference and relevant special services to the users in this digital age.

\section{References}

Fosket, D.J (1965). Comparative librarianship. London: Clive Bingley.

IFLA (International Federation of Library Association) 1994. Public library manifesto. Paris www.IFLA.org

Iyer, V.K (1999). Public library system in India. New Delhi: Rajat publication.

KNLS (Kenya National Library Service) 2005: Historical Background. - Available:

http://www.knls.org.ke/history.htm (18/08/08)

Kothari, C R (1985). Research methodology. New Delhi: New age international publisher.

Sager, J. Donald (1984). Managing the public library. New York: Knowledge industry publications.

Thompson, James (1974). Library power .London: Clive Bingley. 
UNESCO (United Nations Educational, Scientific, and Cultural Organization) (1994). Public library manifesto 1994' IFLA Public library news, No 12.

UNESCO/IFLA (1981). Questionnaire on statistics of libraries ,Paris 